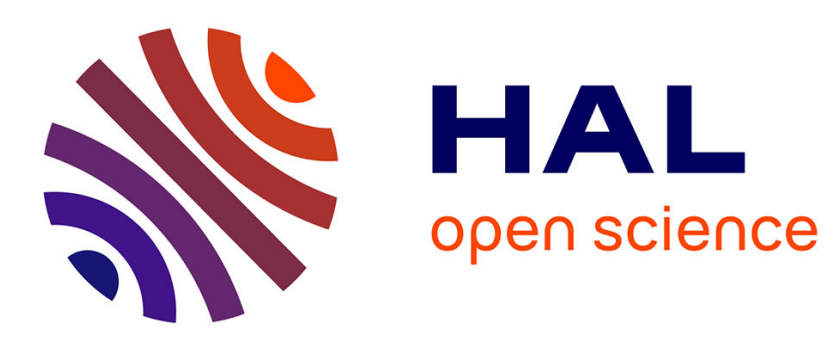

\title{
Promoting self-employment: Does it create more employment and business activity?
}

Gilbert Cette, Jimmy Lopez

\section{To cite this version:}

Gilbert Cette, Jimmy Lopez. Promoting self-employment: Does it create more employment and business activity?. LABOUR, 2021, 36 (1), pp.94-114. 10.1111/labr.12211 . hal-03588286

\section{HAL Id: hal-03588286 \\ https://hal.science/hal-03588286}

Submitted on 24 Feb 2022

HAL is a multi-disciplinary open access archive for the deposit and dissemination of scientific research documents, whether they are published or not. The documents may come from teaching and research institutions in France or abroad, or from public or private research centers.
L'archive ouverte pluridisciplinaire HAL, est destinée au dépôt et à la diffusion de documents scientifiques de niveau recherche, publiés ou non, émanant des établissements d'enseignement et de recherche français ou étrangers, des laboratoires publics ou privés. 


\title{
Promoting self-employment: Does it create more employment and business activity?
}

\author{
Gilbert Cette* and Jimmy Lopez**
}

September 2021

\begin{abstract}
:
We assess the economic impact of reforms promoting self-employment in the three countries that have implemented such reforms since the early 2000s: the Netherlands, the United Kingdom and France. To that end, we use an unbalanced cross country-industry dataset of 4,226 observations, including 12 OECD countries and 20 market industries, over the 1995-2016 period.

We first observe, using country-level data, that the share of self-employed workers in total employment is quite stable or declines over the period in all countries in our dataset, except in the three countries where large reforms promoting self-employment have been implemented, and only after these reforms. We econometrically confirm this impact on self-employment in our set of 20 industries and we find that, at the end of the period, the reforms may have increased the share of selfemployed workers in total employment by 5.5pp on average in the Netherlands, $2.5 \mathrm{pp}$ in the United Kingdom and $2 \mathrm{pp}$ in France. Then, we investigate the impact of reforms on total employment and value added using a difference-in-differences approach. In spite of a broad sensitivity analysis, we find no evidence that the reforms may have impacted either total employment or value-added. These results suggest that the reforms promoting self-employment may have raised the number of self-employed workers, but mostly through a substitution effect between the self-employed and employees, and not through a supply effect or a substitution effect with informal activities. This means that the reforms may have failed to achieve their main objectives.
\end{abstract}

Keywords: self-employment, entrepreneurship, structural reforms

JEL codes: H24, J21, J38, K31

* : Banque de France and NEOMA Business School, gilbert.cette@neoma-bs.fr

** : Banque de France and Université de Bourgogne Franche-Comté (LEDI), jimmy.lopez@u-bourgogne.fr

The views expressed in this paper are the authors' and do not necessarily reflect those of the institutions they belong to.

The author declares that he has no relevant or material financial interests that relate to the research described in this paper 


\section{Introduction}

Over the last two decades, several developed countries have slightly decreased some of the advantages available for the self-employed. In contrast, as described by the OECD (2019), three countries have implemented important reforms to promote self-employment: the Netherlands and the United Kingdom from the early 2000s and France from the late 2000s. These reforms consist both in a decrease of the administrative burdens on self-employment and a decrease in the fiscal and social taxes levied specifically on these types of jobs.

These reforms could have an economic impact through three different types of channels:

- Supply effects. Lowering administrative burdens and introducing fiscal and social tax advantages for the self-employed provide incentives for entrepreneurship and for activities in industries where production can be done by the self-employed. Self-employed activities become more profitable and then more attractive. The impact of this pure supply effect should be more value-added and more self-employed workers, not more employees but more total employment only from more selfemployed workers.

- Substitution effects between informal and formal activities. Lowering administrative burdens and lowering costs for the self-employed make this type of declared activity more attractive compared to informal and undeclared ones, which are associated with a risk of sanctions in the event of an audit. The pure impact of this channel should be more self-employed workers, not more employees but more total employment, and not necessarily more value-added in the national accounts, as accountants usually try to take into account informal activities in value-added measurements, to get a better evaluation of GDP at the country level.

- Substitution effects between the self-employed and employees. Lowering administrative burdens and lowering costs for the self-employed make these types of jobs more attractive compared to employee ones. The impact of this pure substitution effect should be more self-employed workers and fewer employees, with no significant change in total employment or in the value-added produced.

These three different channels could in reality act together, due to different reasons. One of these reasons is that the complementarity between employees and self-employed people is not nil, even more at the industry or the global level. None of these three channels act solely, but the hierarchy of their impact is paramount for policy-makers. When states implement reforms promoting selfemployment, they expect impacts corresponding mainly to the first and second channels. From official declarations, it appears clearly that this has been the goal for the three countries which have implemented such reforms since the early 2000s. But if the third channel is the only one activated, then this means the reforms have failed.

Few papers have looked at the economic impact of such reforms. Using individual data for France, Aghion et al. (2017) showed that, among the reforms promoting self-employment, only the simplification of the administrative burden has led to an increase in the number of self-employed. Using macro-data, similar results were obtained by Bosch and de Boer (2017) for the Netherlands and by Adam et al. (2017) for the UK. Katz and Krueger (2016) concluded, using US data, that selfemployment and other alternative work arrangements have an impact on inequality. Bruce (2000) analyzed US data to assess the impact on the probability of entry of changes in marginal or average taxation. Gentry and Hubbard (2000) showed, with US data, that a progressive marginal tax rate impacts entry into self-employment and into business ownership. An abundant literature has also been devoted to the impact of tax reforms for the self-employed on government tax receipts (for a review of the literature, see Aghion et al., 2017). But to the best of our knowledge, there has been no analysis of the impact of such reforms on overall employment and activity. 
In this paper, we first check that self-employment has increased after the reforms in the three countries (The Netherlands, the United Kingdom and France) which have implemented them in the last two decades. More precisely, in all countries of our analysis, there are numerous reforms that may have had a direct or indirect impact on self-employment. Our analysis focuses on the main reforms implemented to promote self-employment in the last two decades according to OECD $(2019$, Chapter 4). In this publication, the OECD considers that the scale of reforms concerning self-employment is not the same between these three countries and the others. That's why we detail below these types of reforms only for these three countries.

Then, the aim of our analysis is to propose an evaluation of the impact of these reforms on total employment and value-added in order to see which of the three channels was activated in each of these three countries. ${ }^{1}$

To estimate the impact of the reforms, we use cross country-industry panel data from the OECD STructural ANalysis (STAN) database on the number of self-employed workers, the total number of workers and value-added in real terms. After cleaning, our main estimation sample is an unbalanced panel of 4,226 observations, including 12 OECD countries and 20 market industries over the 1995-2016 period.

We first observe that in all countries in our dataset the share of self-employed workers in total employment is quite stable or declines over the period, except in the three countries where reforms promoting self-employment were implemented (the Netherlands, the United Kingdom and France). In these three countries, after remaining stable or even declining, the share of self-employed workers increases from the 2000s, and more specifically following the implementation of the reforms. This result is consistent with those of Bosch and de Boer (2017) for the Netherlands, Adam et al. (2017) for the UK or Aghion et al. (2017) for France.

We then test econometrically this observation for our set of 20 industries by estimating a relation explaining the share of self-employed workers with post-reform country-year coefficients. These coefficients are found to be positive and significant from the implementation of the reforms. According to our estimation results, the reforms may have increased the share of self-employed workers in total employment at the end of the period by 5.5pp in the Netherlands, $2.5 \mathrm{pp}$ in the United Kingdom and $2 \mathrm{pp}$ in France. In order to check the robustness of these results we also investigate the impact of the reforms for each industry separately and we run a broad sensitivity analysis. We find a positive impact for a large proportion of country-industry pairs, this impact being significant and robust in the most self-employment intensive industries.

We then investigate the impact of the reforms on the logarithm of the total number of workers and the logarithm of value-added in real terms. If the reforms promoting self-employment have an impact on total employment or on value-added, we would expect this impact to be higher in industries that are self-employment intensive. We use a difference-in-differences approach to test this assumption. This method is all the more relevant as the between industry differences in intensity of use of selfemployment: (i) are high on average; and (ii) are stable over-time as well as between countries. Using

1 Our analysis does not deal at all with the question of platform activities (such as Uber or Deliveroo) for at least three reasons. First, our data end in 2015, at the very beginning of the development of such platforms. Second, we show that the impacts of these reforms are observed almost immediately after their implementation, long before the emergence of platforms. Third, the development of these platforms occurred in all developed countries, and our estimates evaluate the impact of reforms through differences in the evolutions of some variables in these countries compared to the others. 
this approach on our cross country-industry panel data, we find no evidence of any impact of the reforms either on total employment or on value-added in spite of a broad sensitivity analysis.

These results suggest that the reforms promoting self-employment may have increased the number of self-employed workers, but mostly through a substitution effect between the self-employed and employees, not through a supply effect or a substitution effect with informal activities. Only the third channel distinguished above appears to be significant, which means that the reforms may have failed to achieve their main objectives. To the best of our knowledge, such results are original and should of course be confirmed by other studies.

Section 2 describes the reforms aimed at promoting self-employment in the Netherlands, the UnitedKingdom and France, section 3 presents the dataset used and the estimated models, section 4 comments on the estimate results and section 5 concludes.

\section{The reforms in the Netherlands, the United Kingdom and France}

Over the two last decades, several countries have slightly changed the regulations concerning selfemployment, or introduced differences in fiscal and social tax obligations between independent workers and employees. In some countries, for instance the Czech Republic since 2004, Austria since 2008 or Italy since 2012, the main goal of these changes has been to decrease the number of fake selfemployed workers trying to benefit from the social or fiscal advantages relative to employees. In these countries, such reforms have at least partly removed the fiscal and social tax advantages of selfemployment (see OECD, 2019, Chapter 4).

In contrast, in certain other countries, policy choices have developed strong incentives for selfemployment over other forms of employment. As described by the OECD (2019, Chapter 4), this mainly concerns three countries: the Netherlands, the United Kingdom and France. In these three countries, the two goals of the reforms were to create an effective supply shock ultimately boosting activity and employment, and to provide incentives for some informal workers to switch to formal and declared jobs.

In the Netherlands, as described by Bosch and de Boer (2017), several tax policies favouring selfemployed income were implemented or strengthened from 2001 onwards. More specifically, three types of tax reforms were successively implemented. The major tax reform in 2001 lowered marginal tax rates for most self-employed workers and wage earners, and the introduction of an earned-income tax credit sharply reduced marginal tax rates on lower income levels, which might have affected more self-employed workers than employees. Second, in 2001 and 2005, a tax exemption was introduced and increased, especially for self-employed workers on a relatively low income. This higher tax exemption lowered taxable income and the effective marginal tax rates, more for the self-employed than for employees. A third reform was the introduction of a profit rate exemption in 2007. This was designed to balance the tax treatment of self-employed workers paying personal income tax and owners of small corporations paying income tax. This profit rate exemption was increased even more over the period 2007-2010. On top of these three waves of tax reforms, the social contribution rates are lower for self-employed than for employees. The OECD (2019, Chapter 4) estimates that, as a result of these reforms, total employment costs for the average wage are around $30 \%$ higher for traditional employees than for the self-employed. ${ }^{2}$ The reforms introduced and developed from 2001 onwards have provided strong incentives for self-employment compared to formal employment.

2 For a detailed presentation of the income and social tax system in the Netherlands, see Milanez and Bratta (2017). 
In the UK, Adam et al. (2017) describe how incentives for the self-employed and for owner-manager forms of employment were promoted from the early 2000s. In 2000-2002 and 2002-2006, the lower marginal profit tax rates were decreased. This was also the case for the first $£ 5000$ of dividends in 2016-2017. In 2014, social taxes were decreased by up to $f 2000$ for employers. The impact of these tax reforms was amplified by the fact that owner-managers and self-employed workers can split business profits among multiple individuals (for instance with a spouse), reducing their overall average tax rates since marginal tax rates rise with individual income. In addition, eligibility for the working tax credit requires that individuals work a minimum number of hours a week and, compared with an employee, a self-employed worker or owner-manager can easily pretend to work more hours than he/she really does. These reforms were expressly implemented with the aim of promoting entrepreneurship, and to incentivise workers to identify as self-employed.

In France, a new status called "auto-entrepreneur" was created in 2008 and implemented as of 2009, and in 2011 was replaced with the "micro-entrepreneur" status. All administrative tasks for the creation and organisation of this type of small self-employment firm were highly simplified. The fiscal and social contribution rates for "auto-entrepreneurs" were merged into one, which was a percentage of turnover. This unified tax rate corresponded to a low level of tax compared to the average for standard firms. A turnover threshold was decided to make sure that this new status concerned only very small firms. The status was modified in 2011 and 2015 with three types of changes. First, the activity threshold was increased. Second, the unified tax rate was also increased. Third, a number of taxes were added, for instance a local one. Even after these changes, the overall tax rate remains attractive, and INSEE (2020) figures show there were almost 1 million micro-entrepreneurs at the end of 2017.

Chart 1 presents the share of self-employed workers in total employment at the country level in the 12 countries in our dataset, from 1990 to 2015 or 2016, depending on the availability of the data. It appears that in all countries in our dataset, this share is quite stable or declines over the period, except in the three countries where reforms promoting self-employment have been implemented (the Netherlands, the United Kingdom and France). In these three countries, after remaining stable or even declining, the share of self-employed workers in total employment has increased since the 2000s, and more specifically from a point corresponding precisely to the dates of implementation of the first reforms (2001 for Netherlands, 2002 for the United-Kingdom, 2008 for France). These developments suggest that the reforms aimed at promoting self-employment have had a significant impact in the three countries.

Chart 1

Share of self-employed workers in total employment at the country level (in \%)

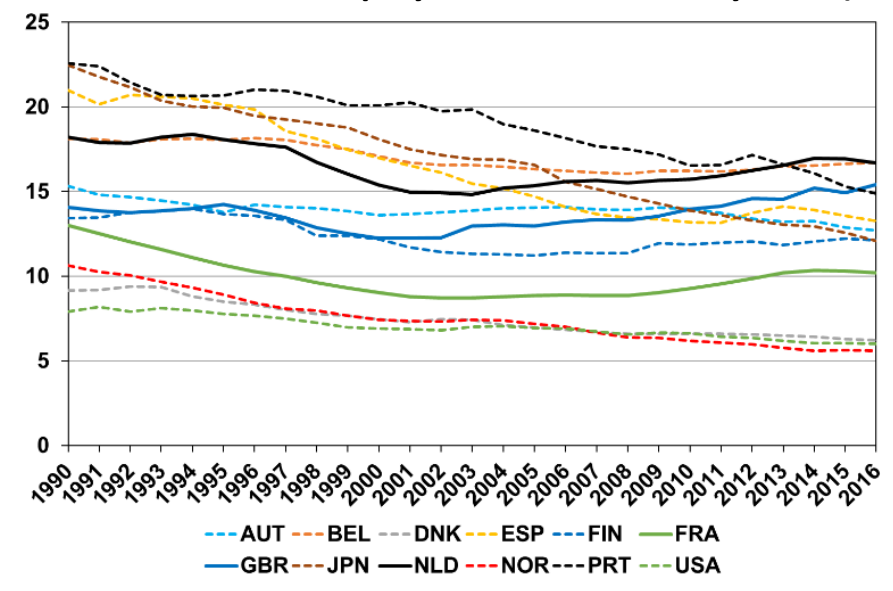

Source: OECD STAN Database 
Chart 2 shows the overall level (on the country scale) of value-added (in real terms), total employment, the number of employees and the number of self-employed workers from 1990 to 2016, in the three countries where reforms have been implemented. Each indicator is based to one at the starting point (1990). In the three countries, the impact of the Great Recession appears clearly: value-added decreases in 2009. The number of self-employed workers accelerates from the dates corresponding to the implementation of the reforms. But total employment and value-added do not accelerate from the same moment. Even more importantly, the number of employees seems to decelerate after the implementation of the reforms. This suggests that the reforms have had a mixed impact with, at least partly, a substitution effect between employees and self-employment, in favor of the latter. These evolutions suggest there might be a benefit in using an econometric approach to distinguish and estimate the supply and substitution components of the impact of the reforms. Such an approach is proposed in this paper.

\section{Chart 2}

Value-added (in real terms) and employment in the Netherlands, the United Kingdom and France $1990=100$
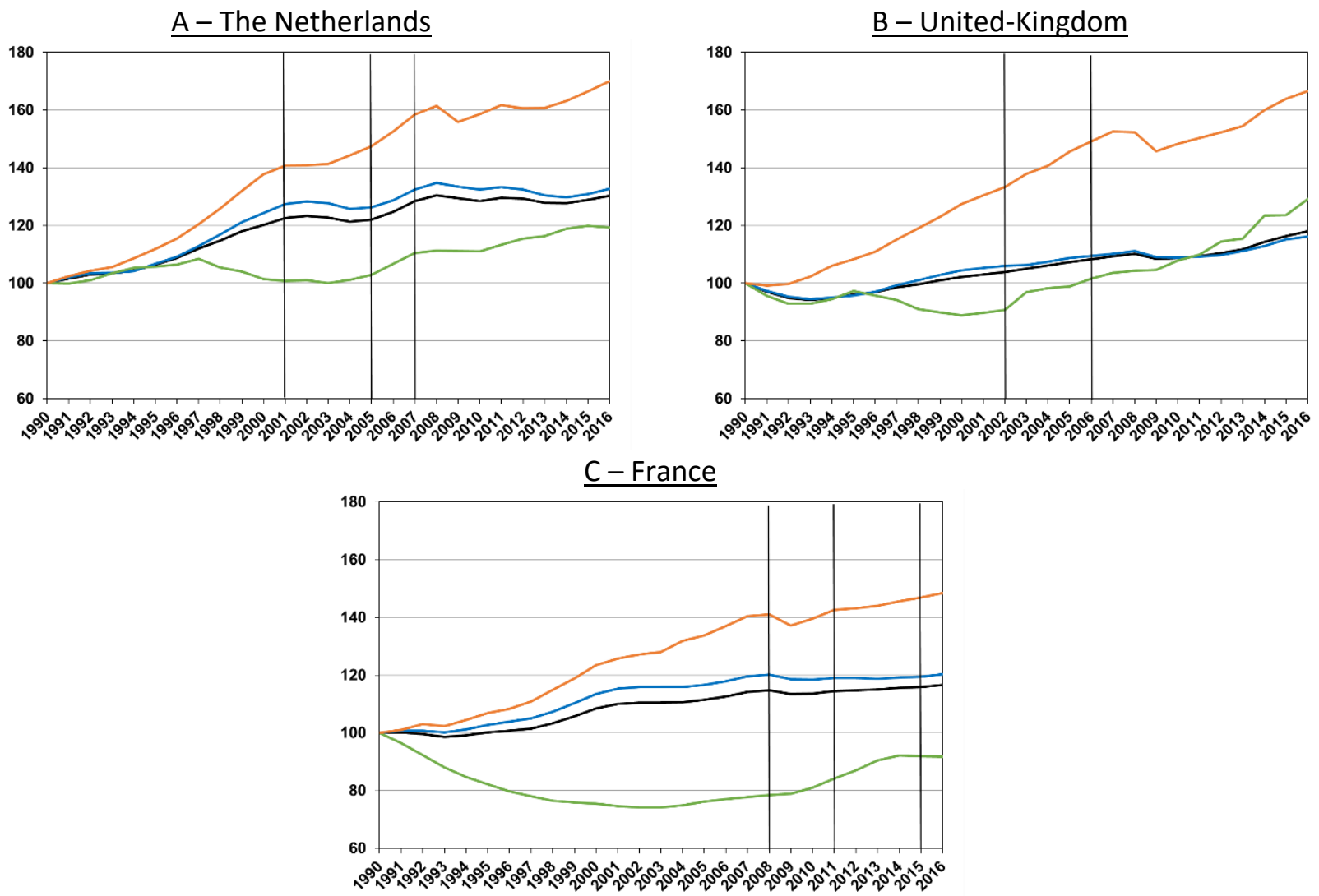

—: Total employment; —: Employees; —: Self-employed; —: Value-added (in real terms) Lecture note: the number of self-employed workers in The Netherlands increased by $19.4 \%$ between 1990 and 2016.

Vertical bars indicate the dates of the main reforms (however, the implementation of some of them has required many years).

Source: OECD STAN Database. 


\section{Data \& Model}

We present successively the database (3.1.) and the estimated models (3.2.).

\subsection{The database}

In order to estimate the impact of the reforms promoting self-employment, we use cross countryindustry panel data on the number of self-employed workers, the total number of workers and valueadded in real terms from the OECD STructural ANalysis (STAN) database. The number of self-employed workers is not directly provided in the STAN database, so we compute this variable as the difference between the total number of workers and the number of employees. Therefore, our measure of selfemployed encompasses a number of distinct legal forms. This point is particularly relevant for the UK, where three categories of workers are distinguished in the law, with different levels of rights and obligations: "employee", "worker" and "self-employed". It is not the case in the Netherlands and France where only two types of workers are distinguished: "employee" and "self-employed". The category "worker" in the UK is intermediate in terms of rights and obligations, to the two other categories. We don't have any data, even more at the sectorial level, concerning the number of "workers" in the UK. So, in this study, our calculation includes implicitly the "worker" in the category "self-employed" which, as far as we know, seems reasonable. After cleaning, our main estimation sample is an unbalanced panel of 4,226 observations, including 12 OECD countries ${ }^{3}$ and 20 market industries (Appendix A presents the list of industries) over the 1995-2016 period.

Chart 2 in the previous section has already shown the change over time of the different variables at the country level. The 20 industries in our estimation sample cover $60 \%$ of total country employment on average. The country average changes observed in our sample are very similar to the country evolutions: an increase in the share of self-employed workers after the reforms, but not in total employment or value-added.

A characteristic of the share of self-employed workers in total employment is that it differs greatly between industries. Our analysis will take advantage of that. Chart 3 shows that the sample average industry share of self-employment is higher than $10 \%$ in 6 industries, whereas this share is lower than $5 \%$ in 10 industries. Most importantly, these between-industry differences are common to the 12 countries in our sample. Indeed, the variance analysis of the share of self-employed workers presented in Table 1 shows that industry differences account for a large part of the variance (57\%), whereas country or year differences account for respectively $9 \%$ and $0.1 \%$ only.

3 The 12 countries in our main estimation sample are: Austria, Belgium, Denmark, Finland, France, Germany, Japan, Netherlands, Norway, Portugal, Spain, United-Kingdom, USA. Data for six ex-communist countries (Czech Republic, Germany, Hungary, Poland, Slovakia \& Slovenia) were also available but are excluded from our main estimation sample as the trends in their share of self-employed workers in the 1990s (i.e. in the prereform period) were generally very different from the trends observed in the other countries. However, our estimation results are robust to the inclusion of these countries in the estimation sample. 


\section{Chart 3:}

Industry share of self-employed (in \%)

(sample average per industry)

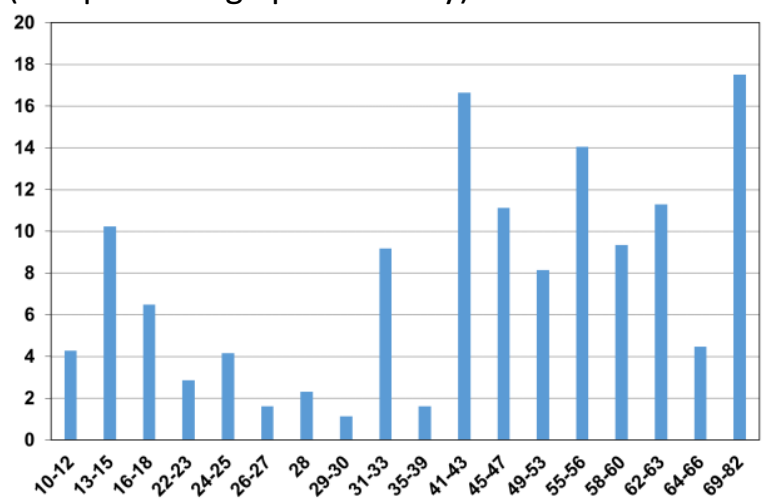

Lecture note: the share of self-employed in 'Food products, beverages and tobacco' (ISIC rev. 4 code ' $10-12$ ') industry is $4.3 \%$ on average on our sample.

Appendix A presents the list of industries.
Table 1:

Share of self-employed variance analysis

\begin{tabular}{|c|c|c|}
\hline \multicolumn{2}{|c|}{ Total Sum of Square } & 19.01 \\
\hline \multirow{6}{*}{ 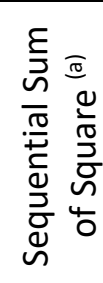 } & Country & 1.73 \\
\hline & Industry & 10.90 \\
\hline & Year & 0.02 \\
\hline & Country*Industry & 5.50 \\
\hline & Industry*Year & 0.27 \\
\hline & Country*Year & 0.12 \\
\hline \multicolumn{2}{|l|}{$\mathrm{R}^{2}$} & 0.975 \\
\hline \multicolumn{2}{|c|}{ Observations } & 4226 \\
\hline
\end{tabular}

(a): The sequential Sum of Square (SS) is the incremental improvement in the error SS as each factor effect is added to the regression model.

Lecture note: the country, industry and year fixed effects explain $66.5 \%(=(1.73+10.90+0.02) / 19.01)$ of the variance of the share of self-employed. If we add also the country $x$ industry fixed effects to this set its explanatory power increases to $95.5 \%$ $(=(1.73+10.90+0.02+5.50) / 19.01)$.

\subsection{The estimated models}

The aim of our analysis is to propose an evaluation of the impact of the reforms promoting selfemployment in such a way that we can see whether this impact involves: (i) a supply effect; (ii) a substitution effect between informal and formal activities; and/or (iii) a substitution effect between the self-employed and employees. To this end, we first check whether the post-reform increase in the share of self-employed workers shown in Chart 1 is robust using the fixed effect panel data estimation method. Then, we investigate the impact of these reforms on total employment and on value-added using a difference-in-differences approach relying on the large between industries differences in the share of self-employed.

In order to check for the robustness of the post-reform increase in the share of self-employed workers, we use the following specification:

$$
\text { Inde. } \text { share }_{c i t}=\beta_{t}^{N L D} \times D_{t}^{N L D}+\beta_{t}^{U K} \times D_{t}^{U K}+\beta_{t}^{F R A} \times D_{t}^{F R A}+\phi_{c i}+\mu_{c i} \times t+\phi_{i t}+u_{c i t}
$$

Where:

- Inde.share cit $_{\text {it }}$ is the share of self-employed workers in total employment in country c, industry $i$ and year $t$;

- $\quad D_{t}^{c}$ is a dummy variable equal to 1 for year $t$ in country $c$ after the first major reform in this country (2001 for the Netherlands, 2002 for the United-Kingdom and 2008 for France);

- $\phi_{c i}, \phi_{i t}$ are Country $\mathrm{x}$ Industry and Industry x Year fixed effects respectively;

- $\mu_{c i}$ are Country $\mathrm{x}$ Industry specific coefficients that allow us to capture the Country $\mathrm{x}$ Industry trends;

- $u_{\text {cit }}$ is the error term.

The $\beta_{t}^{N L D}, \beta_{t}^{U K}, \beta_{t}^{F R A}$ coefficients capture the Country $\mathrm{x}$ Year average differences in the share of selfemployed workers after the reform relative to: (i) the Country $\mathrm{x}$ Industry pre-reform trends $\left(\mu_{c i}\right)$; and (ii) the industry changes in the other countries $\left(\phi_{i t}\right)$. The estimation of Country $\times$ Year specific coefficients rather than a single coefficient for the country trend changes enable a smooth assessment 
of the impact of the reforms, which is particularly relevant as the highlighted reforms are followed by some (generally less important) ones. Relation (1) is estimated for the entire set of 20 industries and for each industry separately. These last estimations allow us to focus on industries with a high share of self-employed workers.

Relation (1) specification doesn't prevent endogeneity bias, in particular if governments react to selfemployment changes or if there are confounding factors such as other reforms on the labour markets (the confounding factors and their potential influence on the estimation results are discussed in the next section). Therefore, relation (1) should be considered as a robustness check of the descriptive analysis rather than an identification strategy of a causality link.

Our main original contribution is to investigate the impact of the reforms promoting self-employment on total employment and value-added. The potential endogeneity of these reforms is an important obstacle that we need to deal with. As mentioned in section 3.1, some industries are 'naturally' more intensive users of self-employment. ${ }^{4}$ If the reforms promoting self-employment have an impact on total employment or on value-added, we would expect this impact to be greater in these industries. ${ }^{5}$

Therefore, we use a difference-in-differences approach that prevents endogeneity issues to test this assumption:

$$
\begin{gathered}
y_{c i t}=\beta_{i t}^{N L D} \times D_{i t}^{N L D}+\beta_{i t}^{U K} \times D_{i t}^{U K}+\beta_{i t}^{F R A} \times D_{i t}^{F R A} \\
+\phi_{c t}+\phi_{c i}+\mu_{c i} \times t+\phi_{i t}+u_{c i t}
\end{gathered}
$$

Where:

- $\quad y_{c t}$, the dependent variable, may be the logarithm of the total number of workers or of value-added in real terms;

- $D$, the reform variable, is now equal to one after the reforms only for the six industries with an average share of self-employment higher than $10 \%$ before the reforms (alternative thresholds are also used); ${ }^{6}$

- $\phi_{c t}, \phi_{c i}$ and $\phi_{i t}$ correspond to Country x Year, Country x Industry and Industry x Year fixed effects respectively;

- $\mu_{c i}$ are Country $\mathrm{x}$ Industry specific coefficients that allows us to capture the Country $\mathrm{x}$ Industry trends.

Relation (2) $\beta_{i t}^{N L D}, \beta_{i t}^{U K}, \beta_{i t}^{F R A}$ coefficients capture the difference of impact of the reforms between the industries that are self-employment intensive and the others. This specification may prevents from: (i) reverse causality, when governments reacting to economic situations implement changes in selfemployment policies; (ii) Country $\times$ Year and Industry $\times$ Year omission bias if country or industry economic shocks occur simultaneously with the reforms. Relation (2) is not a 'pure' difference-indifference approach, but a difference-in-difference as in Rajan and Zingalès (1997). Notably, we don't assume that the group of less intensive users of self-employment is untreated, but we test only whether the impact of the reforms is lower in this group than in the group of the most intensive users.

4 As the share of self-employed may depend on the reforms promoting self-employment, it is important to note that the qualification of self-employment intensive sector is made considering the situation before the reforms. So the identification of this group is not endogenous vis-à-vis the reforms investigated. These sectors are prior to the reforms more self-employment intensive users.

5 On the other hand, there is no reason to expect that the impact of the reforms on the share of self-employed workers would depend on the industry average share of self-employment.

6 The list of 6 industries with a share of self-employment higher than $10 \%$ is presented in Appendix A. 


\section{Estimation results}

We present estimates successively for the impact of reforms promoting self-employment on the share of self-employed workers (4.1.) and on total employment and value-added (4.2.), then we discuss the sensitivity analysis of these results (4.3.).

\subsection{Estimated impact on the share of self-employed workers}

Chart 4 presents the estimate results of relation (1) for the set of all industries. More precisely, it presents the estimate values and the confidence interval of the coefficients $\beta_{t}^{N L D}, \beta_{t}^{U K}$ and $\beta_{t}^{F R A}$. It appears that these coefficients are positive and significantly different from 0 , immediately after the reform implementation in the Netherlands and France, and some years after in the United Kingdom. In this last country, the impact of the reforms implemented since 2000-2002 is quite small (around 1\% or less) and not always statistically significant until 2010, maybe because the reforms in this country were targeting mainly the owner-managers of incorporated businesses. ${ }^{7}$ Moreover, despite the use of time fixed effects, the coefficients follow a positive trend for the three countries, with a negative shock on this trend just after the 2008 financial crisis. It suggests an increasing impact of the reforms overtime, which only slowed down from the financial crisis. ${ }^{8}$ All else being equal, these results suggest that, by the end of the period, the reforms had increased share of self-employed workers in total employment by $5.5 \mathrm{pp}$ in the Netherlands, $2.5 \mathrm{pp}$ in the United Kingdom and $2 \mathrm{pp}$ in France.

Our results confirm that the self-employment changes observed in our database are consistent with the results of Bosch and de Boer (2017) for the Netherlands, Adam et al. (2017) for the UK or Aghion et al. (2017) for France. However, it's important to discuss these results in the light of possible confounding factors. In particular, labor market reforms that do not target self-employment may also have an indirect impact on the self-employment share. There were a number of labor market reforms in The Netherlands, the United-Kingdom and France in the 2000-2015 period. Appendix B presents a review of these reforms and allows us to identify the ones that are the most likely to have a possible impact on our estimates. This review emphasizes: (i) the difficulty of attributing to one reform the impacts on the self-employment rate of all the labor market reforms implemented on the same period; and (ii) the need for other identification strategies, such as the relation (2) difference - in difference approach. We discuss below how the different labor market reforms may influence our estimation results.

For The Netherlands and the United-Kingdom, reforms targeting persons with disabilities may have increased the employment rate through employment contracts, thus having a negative impact on the self-employment share, leading to the underestimation of the true impact of self-employment reforms. ${ }^{9}$ At the same time, in The Netherlands, reforms targeting a reduction of the unemployment rate (in 2006, 2009 and 2012) may have had ambiguous effects on the self-employment rate: an increase of total employment would have a negative impact on the self-employment rate, but the reduction of the duration of unemployment benefits may also have increased the incentive to start

7 The estimated coefficients are not always statistically significant for the United-Kingdom when considering a $95 \%$ confidence interval, but would be always significant for a $90 \%$ confidence interval.

8 Using relation (1) specification to estimate the impact of the reforms on total employment and on value added leads to very different results, as shown in the online appendix: there is no evidence at all of an impact on these variables.

9 Reforms targeting the persons with disabilities were implemented throughout the period (in 2002, 2004, 2005, 2006, 2009, 2010, 2012 in The Netherlands and in 2006, 2008 in the United-Kingdom), as most of the reforms discussed in this paragraph, so it would be difficult to distinguish their specific effects from those of the reforms targeting self-employment. 
self-employment activities. For the United-Kingdom, there were also several reforms of the Apprenticeships program implemented over the 2000s, notably targeting adults with low skills, as well as several policies to raise education participation for the 16 and 17-year-old. As the self-employed are more skilled than the rest of the population, we may expect a negative impact of these reforms on the rate of self-employment. Finally, we should also consider that the government increased the Working Tax Credit income threshold in 2008. As this Tax Credit concerns the employees and the self-employed, its impact on the rate of self-employment is ambiguous and depends on the fiscal strategies that the self-employed may use. For France, we should consider mainly the reforms of the pension system implemented in 2003, 2008, 2010 and 2012 because they may have increased the employment rate of older active people. The indirect impact of pension system reforms on the self-employment rate may be negative because older workers are less prone to be self-employed, so the omission of this confounding factor may lead again to the underestimation of the true positive impact of the reforms targeting self-employment.

\section{Chart 4}

Estimated impact of the reforms on the share of self-employed workers in total employment (in \%) (Relation 1 estimate results for the set of all industries)

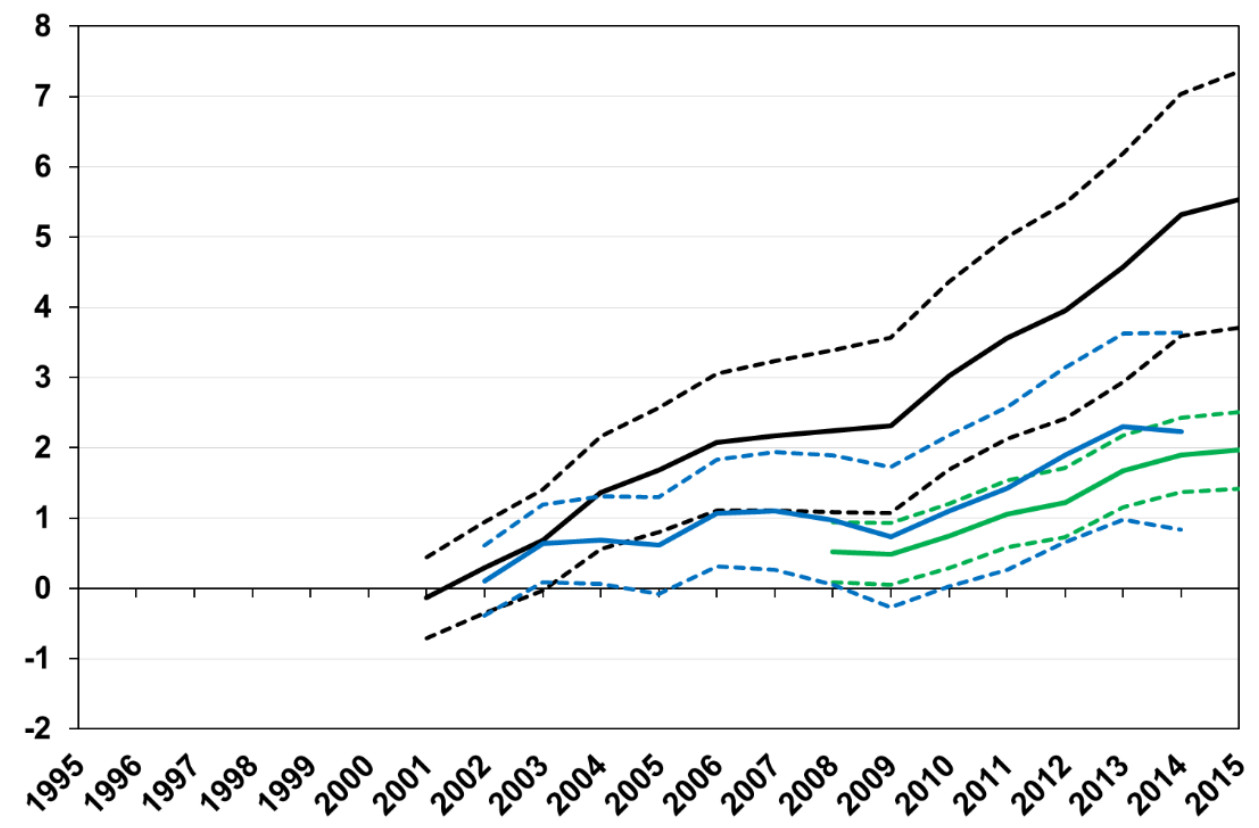

green: France; blue: United Kingdom; black: Netherlands

--: Estimated coefficient; Between -----: 95\% confidence interval

Lecture note: The estimated impact of the reforms on the share of self-employed in The Netherlands in $2015\left(\beta_{2015}^{N L D}\right)$ is $5.5 \%$, with a $95 \%$ confidence interval between $3.7 \%$ and $7.4 \%$.

As relation (1) specification doesn't prevent endogeneity bias, we use in the next section relation (2) difference-in-difference approach to identify the impact of the reforms on total employment and value-added. Before presenting relation (2) estimation results, it's interesting to show relation (1) estimation results when estimated for each industry separately. Charts 5 presents these estimated impacts at the end of the period $\left(\beta_{2015}^{N L D}, \beta_{2014}^{U K}\right.$ and $\left.\beta_{2015}^{F R A}\right)$. It confirms the positive impact of the reforms on the share of self-employed. Indeed, the estimated impact is positive for a large share of countries-industries (42 of the 51 countries-industries available) and always positive when statistically significant, except in one case ('IT and other information services', ISIC code 62-63, in the United 
Kingdom). ${ }^{10}$ Focusing on the six most self-employment intensive industries, the estimated impact of the reform is: (i) always positive for France and always significant except for one industry; (ii) positive and significant for four of the five industries available for The Netherlands; and (iii) also positive for the five industries available for the United-Kingdom, but only one of these estimated impacts is statistically significant. As for relation (1) estimates on the whole set of industries, the effect of the reforms seems lower in the United-Kingdom. We could also note from Charts 5 that the positive impact of reforms seems stronger in the most self-employment intensive industries, but with an important heterogeneity among these industries and between countries.

\section{Chart 5}

End-of-period impact of the reforms on the share of self-employed by industry (in \%)

(Relation 1 estimate results by industry)
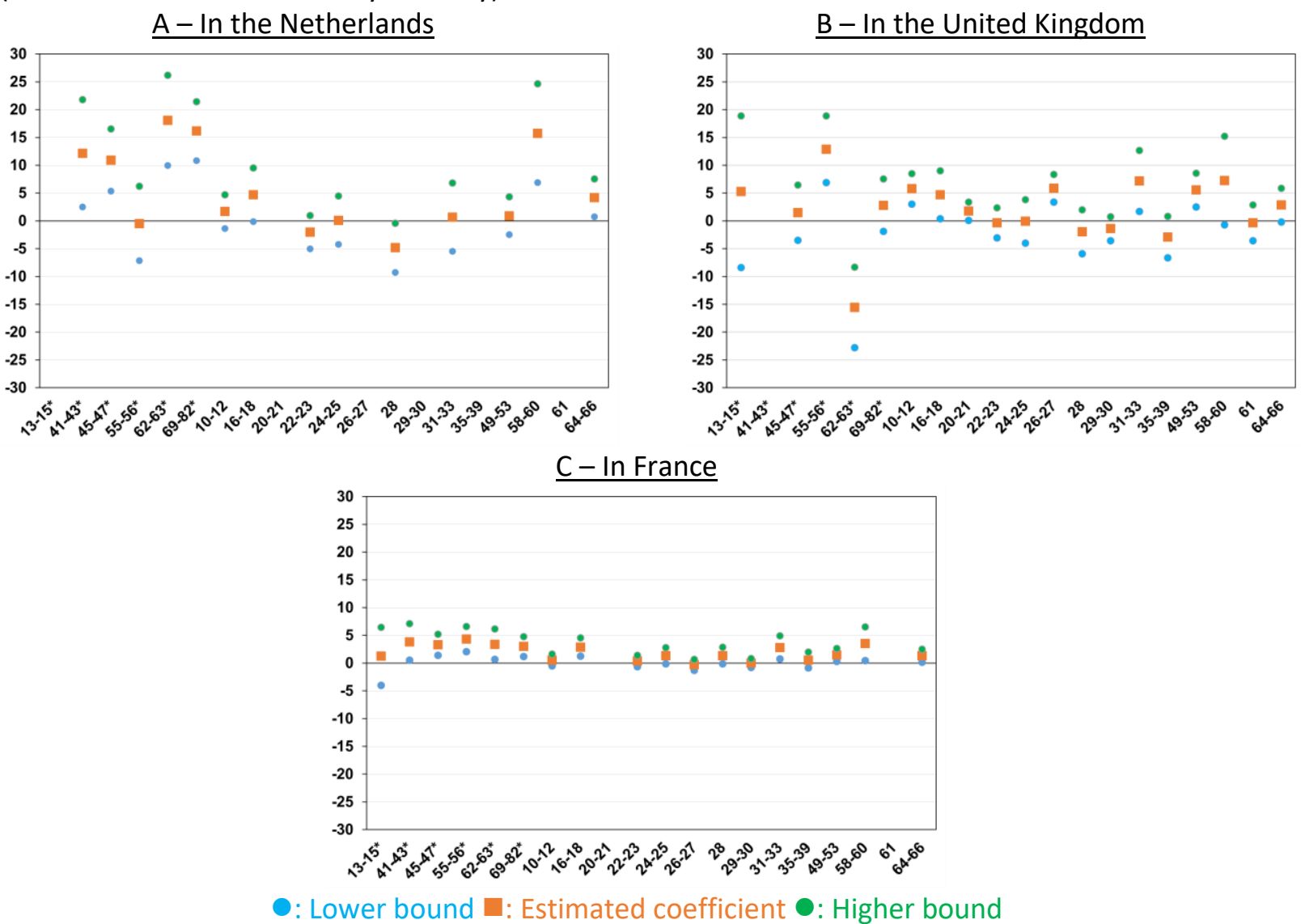

Lecture note: The estimated impact of the reforms on the share of self-employed in The Netherlands in 2015 in the 'Construction' industry (ISIC rev. 4 code ' $41-43$ ') is $12.2 \%$, with a $95 \%$ confidence interval between $2.5 \%$ and $21.8 \%$.Appendix A presents the list of industries.

*: Indicates the 6 most self-employment intensive industries.

\subsection{Estimated impact on total employment and value-added}

If the reforms promoting self-employment had an impact on total employment and value-added, this impact should be stronger in the industries making intensive use of self-employed workers than in others. Relation (2) can be used to test for this difference between industries. Chart 6 shows the

10 Chart 5 presents the end-of-period estimation results, but we find no qualitative difference in the coefficients estimated earlier. It is interesting to note that the impact of the reforms on the share of self-employment increases over time. Estimates five years after the reforms can be obtained from the authors, upon request. 
relation (2) end-of-period estimated impact of the reforms $\left(\beta_{2015}^{N L D}, \beta_{2014}^{U K}\right.$ and $\left.\beta_{2015}^{F R A}\right)$. There is no evidence of a significant difference in impact between the most intensive industries and the others. These results are robust if we focus not on the 6 most intensive industries but on the three most intensive - these three industries being far more intensive than the others - or on the 10 most intensive in our sample of 20 industries (these estimation results are available from the authors upon request). The estimation results are not significant either before the end of the period.

We have mentioned in the previous section the importance of the other labor market reforms as potential confounding factors. They may have an impact on total employment, the share of selfemployment and the value-added. The relation (2) Country $x$ Year fixed effects take into account the average effects of these reforms, thus they may prevent omission bias. An omission bias may still be effective if the effects of these reforms differ for the most self-employment intensive industries from the other industries. However, it's important to notice that we find no significant effects on total employment and value-added of the reforms targeting self-employment. These results may come from an omission bias only if the other labor market reforms compensate 'almost exactly' (or enough to hide) for the 'true' impact of self-employment reforms for each country and for each year.

\section{Chart 6}

End-of-period impact of the reforms in industries making intensive use of self-employment relative to the other industries (in \%)

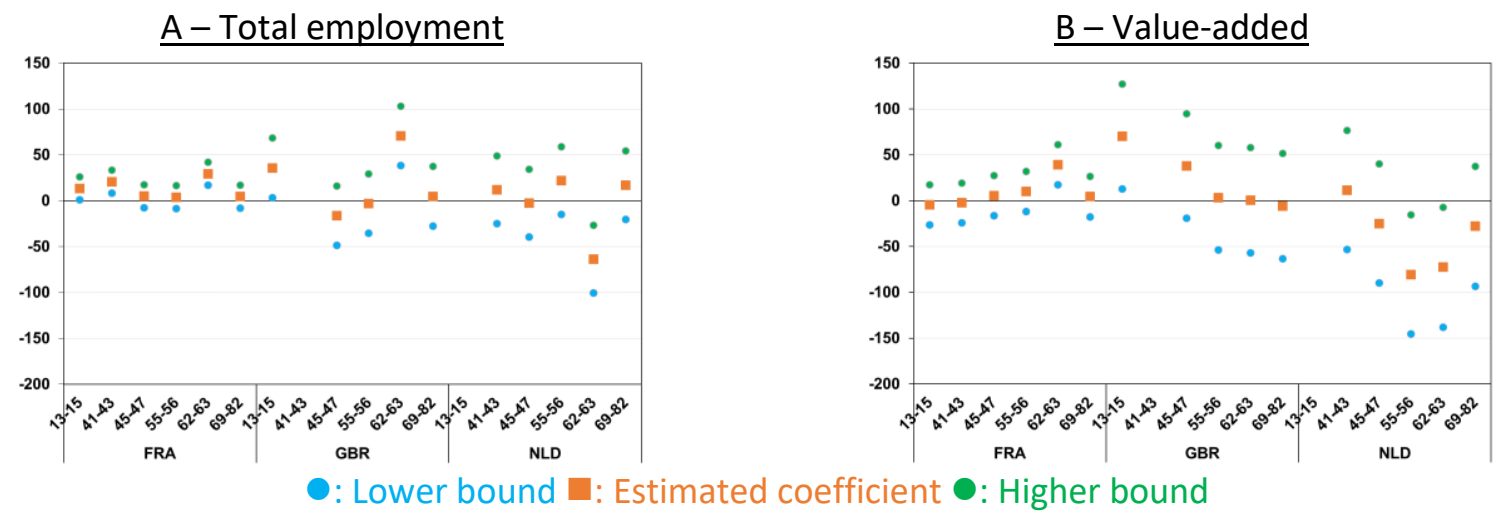

Lecture note: The estimated difference of the impact of the reforms on value-added between the 'Construction' industry (ISIC rev. 4 code '41-43') and the control group (the 14 least self-employment intensive industries) in The Netherlands in 2015 is 11.8\%, with a 95\% confidence interval between $-53.3 \%$ and $76.8 \%$.

Appendix A presents the list of industries.

These results for total employment and value-added in addition to those for the share of self-employed suggest that the reforms promoting self-employment have increased the number of self-employed workers, but mostly through a substitution effect between the self-employed and employees, not through a supply effect or a substitution effect with informal activities. Only the third channel distinguished in the introduction appears to be significant. This means that the reforms have failed to achieve their main objectives.

\subsection{Robustness analysis}

We find a positive impact of reforms promoting self-employment on the share of self-employed workers, which is consistent with Bosch and de Boer (2017) for the Netherlands, Adam et al. (2017) for the UK or Aghion et al. (2017) for France. But we find no evidence of an impact on total employment and on value-added. In order to increase our confidence in these results, particularly for the last ones, our main original contribution, we conduct a broad sensitivity analysis. The impact of the reforms on 
the share of self-employed workers is very robust and we find no significant impact on total employment or value-added (robustness analysis estimates are presented in the online Appendix).

This sensitivity analysis includes for relation (1) and (2):

- Changes in the estimation period. Our main sample starts in 1995, so six years before the first reform, in order to be able to estimate the pre-reform trends. Our estimation results are robust if our sample starts before;

- The exclusion of one country from the estimation sample or the introduction of the 6 ex-communist countries. These 6 countries are omitted from the main estimation sample because their trends in the 90 s (so before the reforms) were very different from those in the three countries with reforms promoting self-employment. Estimation results are very robust to their inclusion in the estimation sample as well as to the exclusion of any country;

- The exclusion of the specific country-industry trends from the estimated specification. These trends allow us to relax the assumption of common trends between countries for a given industry, but their omission leads to a more parsimonious specification. There is still a significant positive impact of the reforms on the share of self-employed workers and no significant impact on total employment and value-added;

- A single country specific coefficient for the impact of the reforms rather than Country $x$ Year specific coefficients, again in order to use a more parsimonious specification. Once more, we find a significant positive impact of the reforms on the share of self-employed workers but not on total employment and value-added.

For the impact on total employment and on value-added, the sensitivity analysis also includes the specifications introduced below and again we find no significant impact of reforms:

- The use of different thresholds to define the group of most intensive industries in terms of selfemployment, as already mentioned;

- The use of the relation (1) specification to estimate the impact of reforms on total employment and value added by industry. This sensitivity analysis is particularly valuable as it can be used to compare its results with the impact of the reforms on the share of self-employed workers estimated with the same approach.

\section{Conclusion}

Using an unbalanced cross country-industry panel dataset of 4,226 observations, including 12 OECD countries and 20 market industries, over the 1995-2016 period, we have proposed an evaluation of the impact of reforms promoting self-employment in the three countries that have implemented them since the early 2000s: the Netherlands, the United Kingdom and France.

The estimate results of a simple model indicate that, by the end of the period, the reforms increased the share of self-employed workers in total employment by 5.5pp in the Netherlands, $2.5 p p$ in the United Kingdom and 2pp in France. Industry-specific estimates indicate that, in the three reforming countries, the reforms promoting self-employment may have increased the number of self-employed workers, but mostly through a substitution effect between the self-employed and employees, not through a supply effect or a substitution effect with informal activities. It means that the reforms may have failed to achieve their main objectives. To our knowledge, such results are original and should of course be confirmed by other studies. 


\section{$\underline{\text { References }}$}

Adam, Stuart, Hellen Miller and Thomas Pope (2017): “IFS Green Budget 2017 “, Chapter 7: "Tax, legal form and the gig economy", Report from the Institute for Fiscal Studies, 07 February.

Aghion, Philippe, Ufuk Akcigit, Matthieu Lequien and Stefanie Stancheva (2017): “Do entrepreneurship and Self-Employment Respond to Simpler Fiscal Incentives? Evidence from France", mimeo, March 20.

Bosch, Nicole and Henk-Wim de Boer (2017): "The Elasticity of Taxable Income for the Self-Employed: Heterogeneity across Reforms and Income Levels", CPB, Discussion Paper, n 354, 14 June.

Bruce, Donald (2000): "Effects of the United States tax system on transitions into self-employment", Labour Economics, Vol. 7, Issue 5, September, pp. 545-574.

Gentry, William M. and R. Glenn Hubbard (2000): "Tax Policy and entrepreneurial Entry", The American Economic Review, Vol. 90, Issue 2, pp. 283-287.

INSEE (2020): “Emploi et revenue des indépendants”, Collection INSEE Références.

Katz, Lawrence, F. and Alan B. Krueger (2016): "The rise and nature of alternative work arrangements in the United States, 1995-2015", NBER, working Papers, N²2667, September.

Milanez, Anna and Barbara Bratta (2017): "Taxation and the future of work: How tax systems influence choice of employment form", OECD Taxation Working Papers, $n^{\circ} 41$.

OECD (2005 to 2021 yearly report): "Going for growth".

$\operatorname{OECD~(2019):~«The~future~of~work».~}$

Rajan, Raghuram, and Luigi Zingalès (1997): "Financial dependence and growth", The American Economic Review, Vol. 88, Issue 3, pp. 559-586. 
Appendix A: Industry list

\begin{tabular}{|c|c|c|}
\hline & $\begin{array}{c}\text { ISIC } \\
\text { Rev. } 4 \\
\text { code }\end{array}$ & $\begin{array}{c}\text { Sample } \\
\text { average } \\
\text { self-emp } \\
\text { share }\end{array}$ \\
\hline Agriculture, hunting, forestry and fishing & $01-03$ & \\
\hline Mining and quarrying & $05-09$ & \\
\hline Food products, beverages and tobacco & $10-12$ & $4.3 \%$ \\
\hline Textiles, wearing apparel, leather and related products & 13-15 & $10.2 \%$ \\
\hline Wood and paper products, and printing & $16-18$ & $6.5 \%$ \\
\hline Coke and refined petroleum products & 19 & \\
\hline Chemical and pharmaceutical products & $20-21$ & $2.9 \%$ \\
\hline $\begin{array}{l}\text { Rubber and plastics products, and other non-metallic mineral } \\
\text { products }\end{array}$ & $22-23$ & $4.2 \%$ \\
\hline $\begin{array}{l}\text { Basic metals and fabricated metal products, except machinery } \\
\text { and equipment }\end{array}$ & $24-25$ & $1.6 \%$ \\
\hline Electrical, electronic and optical equipment & $26-27$ & $2.3 \%$ \\
\hline Machinery and equipment n.e.c. & 28 & $1.1 \%$ \\
\hline Transport equipment & $29-30$ & $9.2 \%$ \\
\hline $\begin{array}{l}\text { Furniture; other manufacturing; repair and installation of } \\
\text { machinery and equipment }\end{array}$ & $31-33$ & $1.6 \%$ \\
\hline $\begin{array}{l}\text { Electricity, gas and water supply; sewerage, waste management } \\
\text { and remediation activities }\end{array}$ & $35-39$ & $16.7 \%$ \\
\hline Construction & $41-43$ & $11.1 \%$ \\
\hline $\begin{array}{l}\text { Wholesale and retail trade, repair of motor vehicles and } \\
\text { motorcycles }\end{array}$ & $45-47$ & $8.2 \%$ \\
\hline Transportation and storage & $49-53$ & $14.1 \%$ \\
\hline Accommodation and food service activities & $55-56$ & $9.3 \%$ \\
\hline Publishing, audiovisual and broadcasting activities & $58-60$ & $11.3 \%$ \\
\hline Telecommunications & 61 & $4.5 \%$ \\
\hline IT and other information services & 62-63 & $2.9 \%$ \\
\hline Financial and insurance activities & $64-66$ & $4.2 \%$ \\
\hline Real estate activities & 68 & \\
\hline Professional, scientific and technical activities & 69-82 & $17.5 \%$ \\
\hline Public administration and defence; compulsory social security & 84 & \\
\hline Education & 85 & \\
\hline Human health and social work activities & $86-88$ & \\
\hline $\begin{array}{l}\text { Arts, entertainment, repair of household goods and other } \\
\text { services }\end{array}$ & $90-99$ & \\
\hline
\end{tabular}

In bold: The 6 most self-employment intensive industries.

In italic: Industry excluded from the estimation sample because of measurement issues and/or lack of responsiveness to economic incentives. 


\section{Appendix B:}

\section{A review of the main labor market reforms in the Netherlands, the United Kingdom and France}

There were a number of labor market reforms in The Netherlands, the United-Kingdom and France in the 2000-2015 period. This appendix introduces the main reforms and intends to identify the ones that may be confounding factors with an impact on our estimation results (for a review of all the structural reforms, see OECD 2005 to 2021).

In the Netherlands, a large part of the labor market reforms over the 2000-2015 period concerns persons with disabilities. In 2002, a law on improved gate-keeping took effect in the disability benefit scheme, and a single employee benefits agency (UWV) was created. In 2004, the waiting period for disability benefit eligibility (required to be spent on sickness leave) was extended to two years. In the same year, a tighter claim-assessment (het Schattingsbesluit) was introduced and a re-evaluation of existing cases started. In June 2005, the Parliament decided on the new disability scheme (WIA), providing stronger financial incentives to work for those with residual work capacity and eliminating benefits for those with modest disabilities. Between 2006 and 2009, a new disability law provided stronger financial incentives to work for those with residual work capacity, a "no-risk policy" with respect to sickness pay for employers hiring partially disabled workers was introduced. Disability benefits were made partly dependent on the hypothetical earnings capacity of benefit recipients. Starting from 2010, new participants in the programme for the young disabled (Wajong) are entitled to job support rather than passive income support. ${ }^{11}$ Finally, the 2012 coalition agreement stipulates that a quota of $5 \%$ of disabled employees in companies, except small ones, will be introduced, with fines in case of unfilled quotas. We must also mention the main other labor market reforms: (i) the special treatment of employers' social security contributions for low-paid workers (SPAK) was abolished in 2003; (ii) the duration of unemployment benefits was reduced in 2006; (iii) in 2008, government and the social partners agreed on capping severance payments at $100 \%$ of the annual pay for workers earning more than EUR 75000 per year and new internal guidelines to determine the amount of severance payments in court cases were adopted (toward a substantial fall in firing costs); (iv) in 2009, the government tightened job requirements for the long-term unemployed and introduced several income-based tax credits to reduce disincentives to higher participation and hours worked for low-income workers and second earners; and (v) the 2012 coalition agreement stipulates also a reduction in the maximum duration of unemployment benefits from 36 to 24 months and a decline of benefits over the unemployment spell as they become based on the minimum wage (instead of the last salary) after 12 months of unemployment. Section 4.1 discusses the influence on the estimation results of the reforms targeting persons with disabilities or a reduction of the unemployment spell in order to alleviate the discussion, but other reforms may also have an indirect impact on self-employment.

In the United-Kingdom, most of the labor market reforms aim to increase person's employability through reforms of education/training and the Pathways to Work programme (a service created to help people with disabilities). Several reforms of the Apprenticeships program has been implemented over the 2000s, notably targeting adults with low skills, as well as several policies to raise education participation for the 16 and 17-year-old, particularly those from poor families. The coverage of the mandatory interview-based process to access the Pathways to Work program was extended to a third of new claimants in 2006, then to all new claimants in 2008 and offered to all existing claimants on a voluntary basis. At the end of 2008 , a new welfare legislation replaced the current system of incapacity benefits by a simplified disability employment allowance. We should note also that the government

11 Participants are assessed upon entry and again at the age of 27 , and can only subsequently be transferred to passive income support. 
has increased the Working Tax Credit income threshold in 2008. These three sets of reforms are discussed in section 4.1 .

In France, some of the reforms targeted and easing of the employment protection legislation. A special permanent contract was introduced for new recruits in firms with less than 20 employees in 2005 but this contract was abolished in $2008 .{ }^{12}$ In 2008, a new fixed-term contract for specific projects was introduced as well as the possibility of mutually agreed termination of permanent contracts (dismissed workers are then able to maintain some of their fringe benefits). However, these reforms seem to have had a limited impact on employment. Reforms concerning the pension system were numerous. In 2003, the retirement ages were raised in line with life expectancy; the private-sector rules were changed to increase the net income of those working beyond the official retirement age; the early retirement programs was scaled back; and using the UI system as a form of early-retirement was made more difficult. Then, between 2008 and 2010, the 'Delalande' contribution (a tax on the firms dismissing workers over 50 years old) was phased out, the pension bonus for working beyond the "normal" length of career was raised and the number of contribution years required for a full pension was increased. Finally, in 2012 the job-search exemption for the older unemployed disappeared. We must also mention other labor market reforms: (i) there were large cuts in social contributions for lowpaid workers in the early 2000s, but this trend has slowed as the minimum wage increased with the harmonisation of the various legal minima that were generated by the legislation on the 35 hours week; (ii) the scheme for social benefits has been changed several times (the main reforms are in 2001 and 2009) in order to improve work incentives; (iii) in 2014, labour taxes have been reduced by 6 percentage points on earnings up to 2.5 times the minimum wage (financed by spending cuts, and VAT and environmental tax increases) and the possibility has been left to businesses and social partners to endorse a firm-level agreement for temporary wage and working time reductions in exchange for a job guarantee in economic downturn.

The reforms implemented in order to ease the employment protection legislation should not impact the estimation results because they include: (i) a special permanent contract introduced in 2005 but abolished in 2008, which could not explain the long-term estimated impact of the reforms targeting self-employment; as well as (ii) a new fixed term contract and the possibility of mutually agreed termination of permanent contracts that had a limited impact on unemployment and total employment. This is also the case for the cut in social contributions for low-paid workers in the early 2000 s, because they are compensated by the minimum wage increase in the same period, and of the reforms implemented in 2014, too late to impact our estimation results. On the contrary, the numerous reforms on the pension system may have had an impact on the employment of the older active persons and so on total employment and thus on the self-employment share.

12 The new contract extends to two years the trial period during which the new recruit can be laid-off under less strict conditions. 